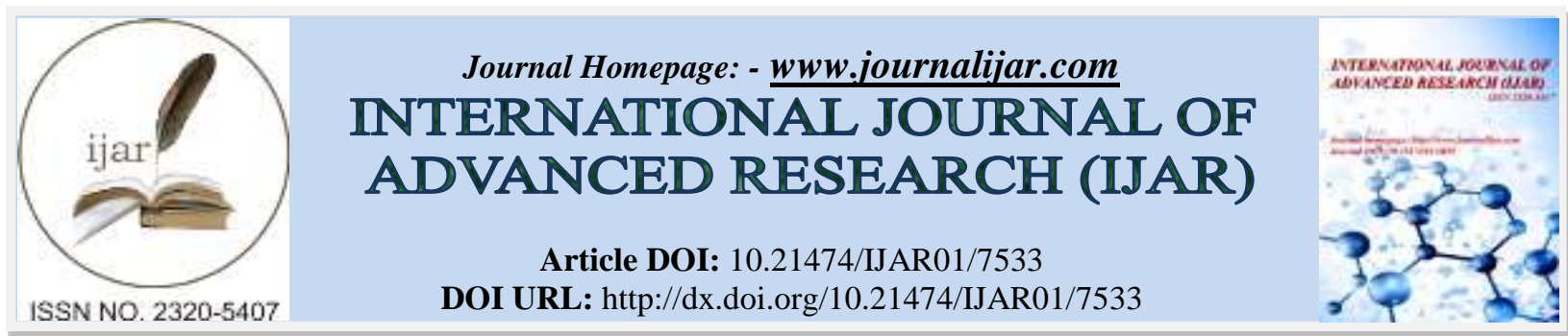

RESEARCH ARTICLE

\title{
"A STUDY TO ASSESS THE EFFECT OF SELF INSTRUCTIONAL MODULE ON THE KNOWLEDGE AND PRACTICES OF THE CARETAKERS RELATED TO ADHERENCE OF DIRECTLY OBSERVED TREATMENT SHORT COURSE AMONG THE CHILDREN SUFFERING FROM TUBERCULOSIS.”
}

Mrs. Bedre Suwarna shriram ${ }^{1}$ and Prof. Dr. Nilima Sonavane ${ }^{2}$.

1. Tutor, College Of Nursing General Hospital Ahemednagar.

2. Associate Professor Department of Community Heath Nursing, Institute of Nursing Education Sir J J Hospital Mumbai.

\section{Manuscript Info}

(..........................

Manuscript History

Received: 11 June 2018

Final Accepted: 13 July 2018

Published: August 2018

Keywords:-

Self Instructional Module, Knowledge,

Practices, Caretakers, DOTS,

Adherence.

\section{Abstract}

Introduction: "Miles to go before I sleep", we still have miles to go before we will make this planet TB free. WHO with its "STOP TB" The famous English poet Robert Frost

Tuberculosis remains a worldwide public health problem despite the fact that the causative organism was discovered more than 100 years ago \& highly effective drugs \& vaccine are available making Tuberculosis a preventable \& curable disease. Tuberculosis (TB) remains a major global health problem ${ }^{1}$ The latest estimates show that there were 8.6 million new TB cases in 2012 and 1.3 million TB deaths globally. India is one of the highest burden countries, accounting for more than 1/5th of the global incidence disease. Apart from being a major public health problem, the economic burden of TB in India is huge and is great loss in terms of lives, money and work hours. ${ }^{1}$

Materials and Methods: The quantitative approach \& PreExperimental one group pre- test \& post - test design was used. As the research problem was aimed at enhancing Knowledge and Practices of the Caretakers related to adherence of Directly Observed Treatment Short Course among the children suffering from Tuberculosis. The sample for the study was $n=50$ selected by using Probability simple random sampling technique. The pre-test was introduced to assess the knowledge and practices among the group of samples on the basis of pre-test result Self-Instructional Module was formulated and introduce to the sample after that the post-test was conducted. 
Results: The result were evaluated through the self structured questionnaire and self-reported observational checklist, The data was analyzed using a paired- $\mathrm{t}$ test to find out the significant difference between pre-test \& post-test mean Knowledge \& Practice scores and inferential statistic method ANOVA applied to evaluate the association between the Knowledge \& Practice scores with the selected demographic variables.

This proved that after administration of SIM, there was improvement in Knowledge \& practices of samples from poor and average range and good range to excellent range which proves effectiveness of SIM.

Conclusion: The results indicated the positive response to the Self Instructional Module for improvement in the Knowledge \& Practices regarding selected aspects of adherence to DOTS. The Caretakers expressed that they were expecting more of such kind of information program with pictures, videos, demonstration and planned teaching.

Copy Right, IJAR, 2018,. All rights reserved.

\section{Introduction:-}

The latest estimates show that there were 8.6 million new TB cases in 2012 and 1.3 million TB deaths globally. India is one of the highest burden countries, accounting for more than $1 / 5$ th of the global incidence disease. Apart from being a major public health problem, the economic burden of TB in India is huge and is great loss in terms of lives, money and work hours. ${ }^{2}$

The United Nations Millennium Development Goal (MDG) for TB is to halt and begin to reverse incidence of the disease by 2015 , with a target of $70 \%$ case detection rate with successful treatment of $85 \%$ of those detected. The aim is to dramatically reduce the global burden of Tuberculosis by ensuring all TB patients, including those coinfected with HIV and those with drug-resistant TB, benefit from universal access to high quality diagnosis and patient-centered treatment In India, since its inception in 1992, RNTCP has evaluated over 55 million persons for TB and initiated treatment for over 15.8 million TB patients. Prevention of mortality has been biggest achievement of RNTCP saving more than 2.8 million lives. ${ }^{2}$

Tuberculosis is an infectious disease caused by the bacteria Mycobacterium Tuberculosis (M-Tuberculosis) also referred as tubercle bacilli Mycobacterium Tuberculosis and characterized pathologically by inflammatory infiltrations. $^{3}$

As per the Global Report on Tuberculosis of 2013 there were an estimated 5, 30,000 TB cases among the children (under 15 years of age) and 74,000 TB deaths (among HIV-negative the children) in 2012 (6\% and 8\% of the global totals respectively). TB is one of top most causes of childhood mortality among 10 major causes of child mortality. Though MDR-TB and XDR-TB is documented among pediatric age group, there are no estimates of overall burden, chiefly because of diagnostic difficulties and exclusion of the children in most of the drug resistance surveys. ${ }^{5}$

Cruz AT et al. (2013), conducted study on 'twice-weekly therapy for the directly observed children with Tuberculosis infection or exposure to determine the safety, adherence and efficacy of intermittent preventive therapy' A total of 1383 the children were treated for 9 months with Isoniazid 20-30 mg/kg/dose or Cap Rifampicin 
$10-15 \mathrm{mg} / \mathrm{kg} /$ dose weekly. When compared to rates of disease progression by age, the efficacy of intermittent DOT was $98 \%$. Resulted as Intermittent DOT in childhood TB is safe, effective and offers high adherence rates. ${ }^{6}$

Liu Q et al. (2014), conducted study on 'reminder systems to improve patient adherence to Tuberculosis clinic appointments for diagnosis and treatment'. People with active Tuberculosis (TB) require six months of treatment. Some people find it difficult to complete treatment, and there are several approaches to help ensure completion. One such system relies on reminders, where the health system prompts patients to attend for appointments on time. ${ }^{7}$

Dr.Angela et al. (2010), conducted a study on 'a systematic review of controlled trials examining interventions that aim to improve medication adherence' comprehensive literature search was undertaken to locate controlled trials that described specific interventions aiming to improve adherence to long-term medication. ${ }^{8}$

The investigator while working in a clinical field, observed that majority of the children suffering with Tuberculosis \& co- infection admitted with HIV-AIDS. The caretaker especially the parents are illiterate \& from the below poverty line. They are not aware about the compliance to the DOTS \& the adverse effect about the non- adherence to DOTS. This inspires researcher to do the study to assess \& improve the Knowledge and Practices of The caretakers related to adherence of DOTS among the children suffering from Tuberculosis with the help of Self Instructional Module.

\section{Objective:-}

1. To assess the Knowledge and Practices of the caretakers among the children suffering from Tuberculosis related to adherence of Directly Observed Treatment Short Course/ DOTS.

2. To assess the effect of Self Instructional Module on Knowledge and Practices of the caretakers among the children suffering from Tuberculosis related to adherence of Directly Observed Treatment Short Course/ DOTS.

3. To determine the association between selected demographic variables with the Knowledge and Practices of the caretakers among the children suffering from Tuberculosis related to the adherence to Directly Observed Treatment Short Course/DOTS.

\section{Materials and Methods:-}

The quantitative approach \& Pre-Experimental one group pre- test \& post - test design was used. As the research problem was aimed at enhancing Knowledge and Practices of the Caretakers related to adherence of Directly Observed Treatment Short Course among the children suffering from Tuberculosis.

The sample for the study was $n=50$ selected by using Probability simple random sampling technique. The pre-test was introduced to assess the knowledge and practices among the group of samples on the basis of pre-test result Self-Instructional Module was formulated and introduce to the sample after that the post-test was conducted and the result were evaluated through the self structured questionnaire and self-reported observational checklist, The data was analyzed using a paired t test to find out the significant difference between pre-test \& post-test mean Knowledge \& Practice scores and inferential statistic method ANOVA applied to evaluate the association between the Knowledge \& Practice scores with the selected demographic variables.

\section{Results:-}

This proved that after administration of SIM, there was improvement in Knowledge \& practices of subject from poor and average range and good range to excellent range which proves effectiveness of SIM. 


\section{Conclusion:-}

During the study it was observed that, all the subjects were very conscious and interested to learn. The results of pretest of the study revealed that there was low level of Knowledge \& Practices in the subjects regarding adherence to DOTS. In post-test there was significant gain in Knowledge \& Practices regarding adherence to DOTS was observed. The results indicated the positive response to the Self Instructional Module for improvement in the Knowledge \& Practices regarding adherence to DOTS. The subjects expressed that they were expecting more of such kind of information programs with pictures, videos, demonstration and planned teaching.

\section{PART-A}

Table 1- Distribution of Subjects according to area wise Knowledge scores regarding disease condition, mode of transmission, sign \& symptoms, treatment \& prevention of Tuberculosis in pre-test \& post-test.

\begin{tabular}{|l|l|l|l|l|l|l|}
\hline \multirow{2}{*}{$\begin{array}{l}\text { Sr. } \\
\text { no }\end{array}$} & Area wise Knowledge & Range & Pre-test & Post-test \\
\hline 1 & & & $f$ & $\%$ & F & $\%$ \\
\hline 2 & Poor Knowledge & $0-3$ & 0 & 0 & 0 & 0 \\
\hline 3 & Average Knowledge & $4-7$ & 21 & 42 & 0 & 0 \\
\hline 4 & Excellent Knowledge & $8-11$ & 29 & 58 & 1 & 2 \\
\hline & Total & $12-13$ & 0 & 0 & 49 & 98 \\
\hline
\end{tabular}

The above table No: 1 highlighted that; majority of the Subjects (58\%) had good Knowledge, (42\%) Subjects had average Knowledge. Whereas in the post-test scores there was improvement in Knowledge scores off the Subjects as (98\%) Subjects had excellent Knowledge. This showed that after administration of SIM there was an improvement in Knowledge score of Subjects which proved effectiveness of SIM.

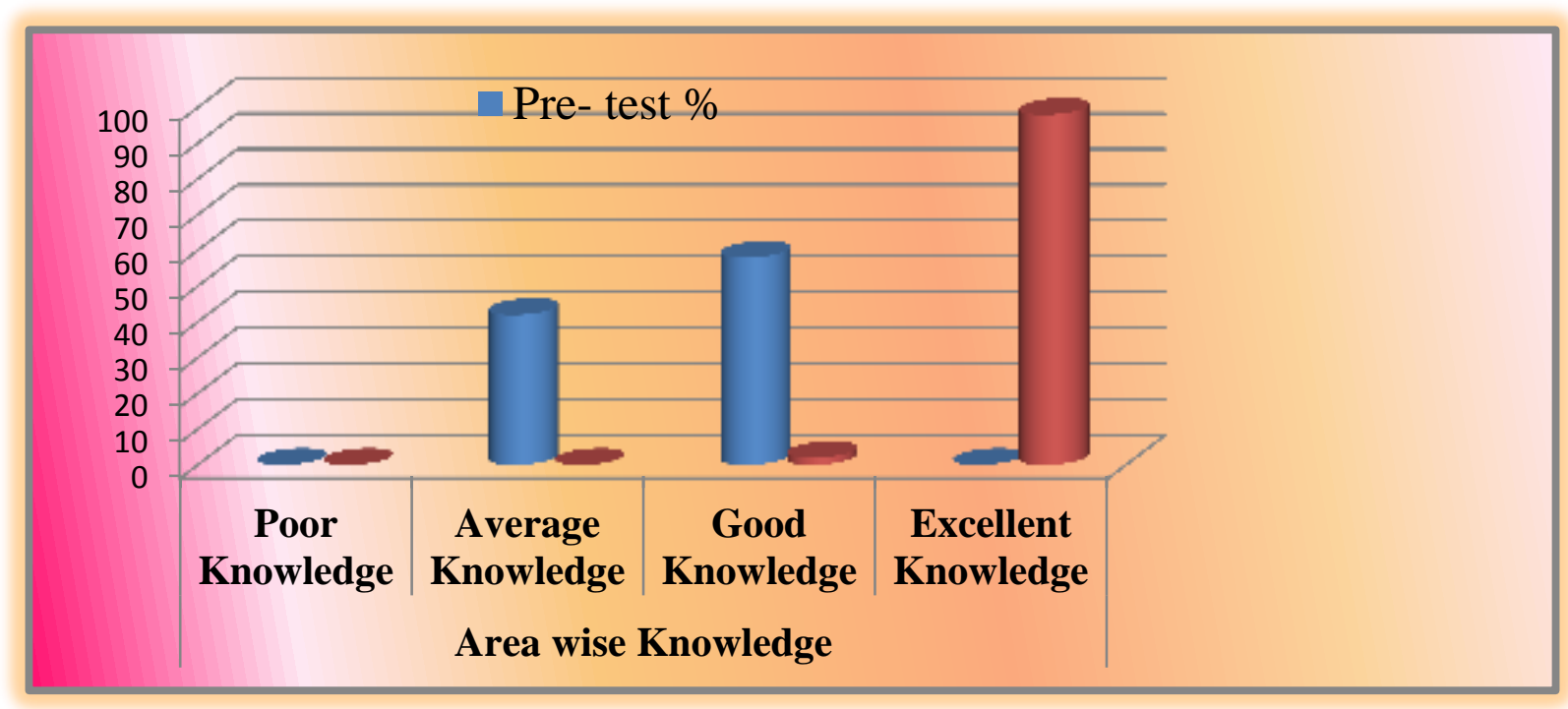

Fig. 1:- Distribution of Subjects according to Knowledge scores regarding disease condition, mode of transmission, sign $\&$ symptoms, treatment $\&$ prevention of Tuberculosis in pre-test \&post-test. 


\section{PART-B}

Table 2- Distribution of Subjects according to the assessment of area wise Knowledge score related to DOTS therapy $\&$ its adherence in pre-test $\&$ post-test.

\begin{tabular}{|l|l|l|l|l|l|l|}
\hline \multirow{2}{*}{$\begin{array}{l}\text { Sr. } \\
\text { no. }\end{array}$} & Area wise Knowledge & Range & Pre- test & Post-test \\
\hline 1 & & & F & $\%$ & F & $\%$ \\
\hline 2 & Poor Knowledge & $0-3$ & 2 & 4 & 0 & 0 \\
\hline 3 & Average Knowledge & $4-7$ & 34 & 68 & 0 & 0 \\
\hline 4 & Excellent Knowledge & $8-11$ & 13 & 26 & 4 & 8 \\
\hline & Total & $12-13$ & 1 & 2 & 46 & 92 \\
\hline
\end{tabular}

The above table: 2 highlighted that, majority of the Subjects $(68 \%)$ had average Knowledge, (26\%) Subjects were having good Knowledge. The post-test score highlighted improvement in Knowledge scores off the Subjects (92\%) Subjects had excellent Knowledge, $(8 \%)$ Subjects were there in a good category. None of the Subjects were there in a poor, average range. This indicated that after administration of SIM there was improvement in Knowledge of the subjects related to DOTS therapy \& its adherence which proved the effectiveness of SIM.

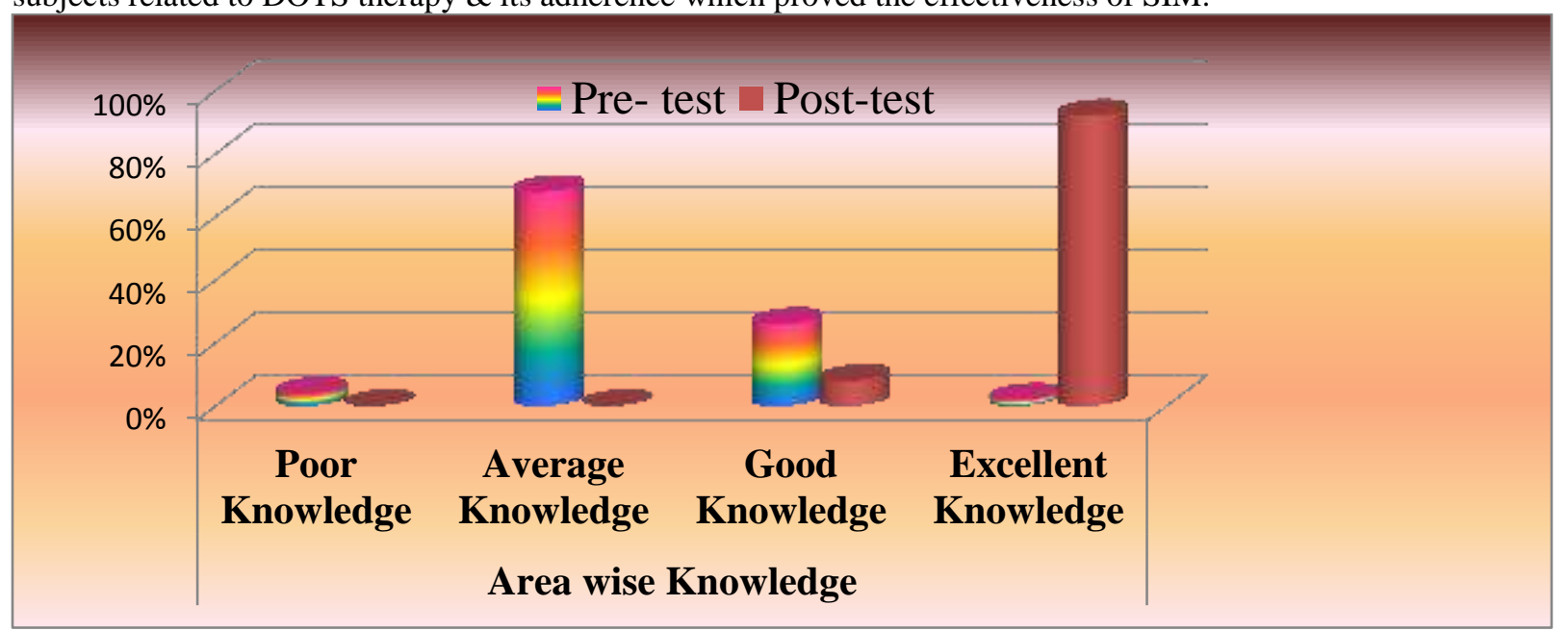

Fig. 2:- Distribution of Subjects according to Knowledge levels regarding DOTS therapy \& its adherence in pre-test \& post-test.

\section{PART-C}

Table 3- Distribution of Subjects according to the overall Knowledge scores in per-test \& post-test.

\begin{tabular}{|l|l|l|l|l|l|l|}
\hline \multirow{2}{*}{$\begin{array}{l}\text { Sr. } \\
\text { no. }\end{array}$} & Overall Knowledge scores & Range & Pre- test & \multicolumn{2}{l|}{ Post-test } \\
\cline { 4 - 7 } & & & $f$ & $\%$ & $f$ & 0 \\
\hline 1 & Poor Knowledge & $0-6$ & 0 & 0 & 0 & 0 \\
\hline 2 & Average Knowledge & $7-13$ & 25 & 50 & 0 & 0 \\
\hline 3 & Good Knowledge & $14-20$ & 23 & 46 & 0 & 0 \\
\hline 4 & Excellent Knowledge & $21-26$ & 2 & 4 & 50 & 100 \\
\hline
\end{tabular}




\begin{tabular}{|l|l|l|l|l|l|l|}
\hline & Total & & 50 & 100 & 50 & 100 \\
\hline
\end{tabular}

The Table 3 indicated that, majority of the Subjects (50\%) had average Knowledge, (46\%) Subjects were having good Knowledge, (4\%) Subjects were there in an excellent category. None of the Subjects were there in a poor range .The post-test score highlighted improvement in overall Knowledge score of the Subjects (100\%) Subjects had excellent Knowledge score.

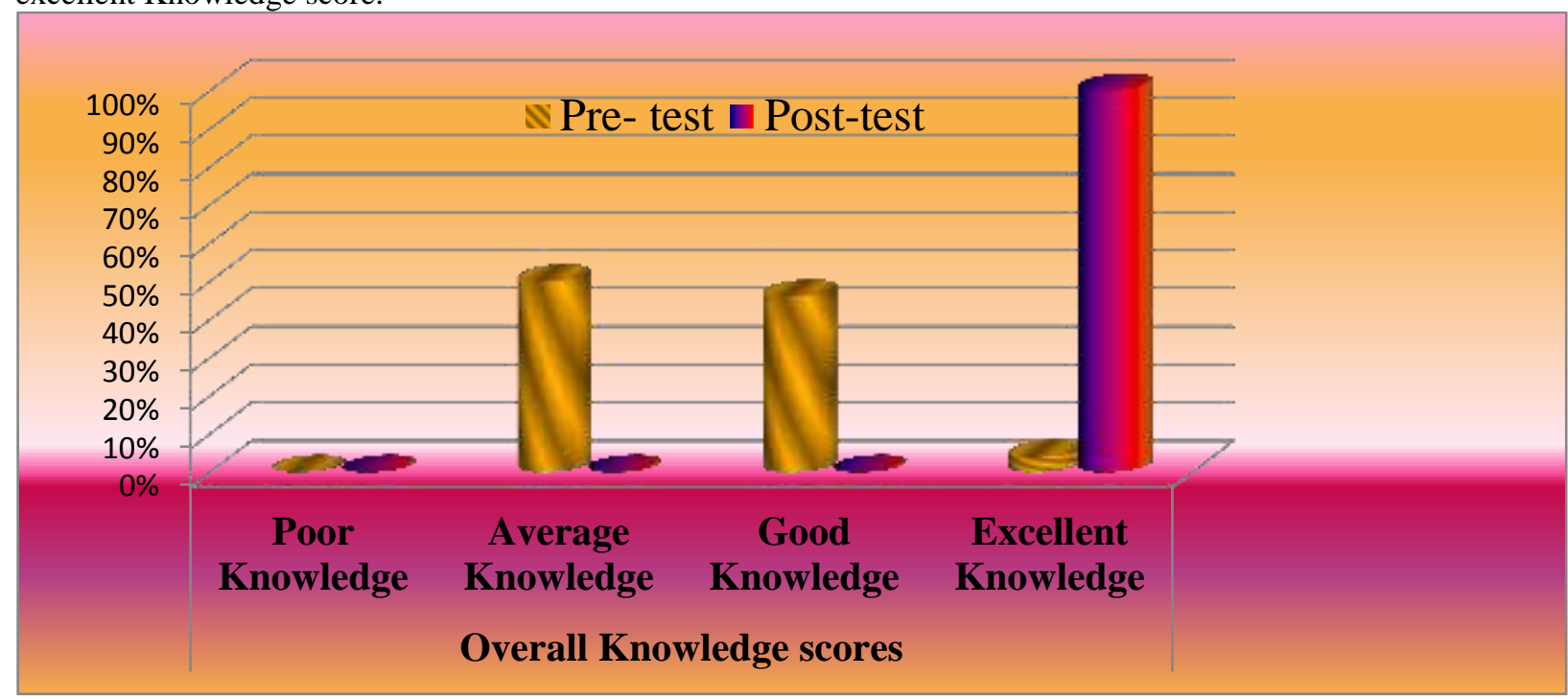

Figure No: 3:- Distribution of Subjects according to the Overall Knowledge scores in pre-test \& post-test.

\section{PART-D}

Table 4- Distribution of Subjects according to the overall reported Practices scores in the pre-test \& post-test.

\begin{tabular}{|l|l|l|l|l|l|l|}
\hline \multirow{2}{*}{$\begin{array}{l}\text { Sr. } \\
\text { no. }\end{array}$} & Overall reported Practices score & Range & Pre-test & Post-test \\
\hline 1 & & & $f$ & $\%$ & F & $\%$ \\
\hline 2 & Poor Practice & $0-3$ & 0 & 0 & 0 & 0 \\
\hline 3 & Average Practice & $4-7$ & 0 & 0 & 0 & 0 \\
\hline 4 & Good Practice & $8-11$ & 13 & 26 & 1 & 2 \\
\hline & Total & $12-14$ & 37 & 74 & 49 & 98 \\
\hline
\end{tabular}

The above table- 4 highlighted that, majority of the Subjects (74\%) had excellent Practice score, (26\%) Subjects were following good Practices. None of the Subjects were there in a poor and average category. The post-test score highlighted improvement in Practices scores of Subjects (98\%) had excellent Practice score, (2\%) Subjects with good Practice score, none of the Subjects were there in poor, average range. This showed that, after administration of SIM there was improvement in Practices scores of Subjects in post-test which proves effectiveness of SIM. 


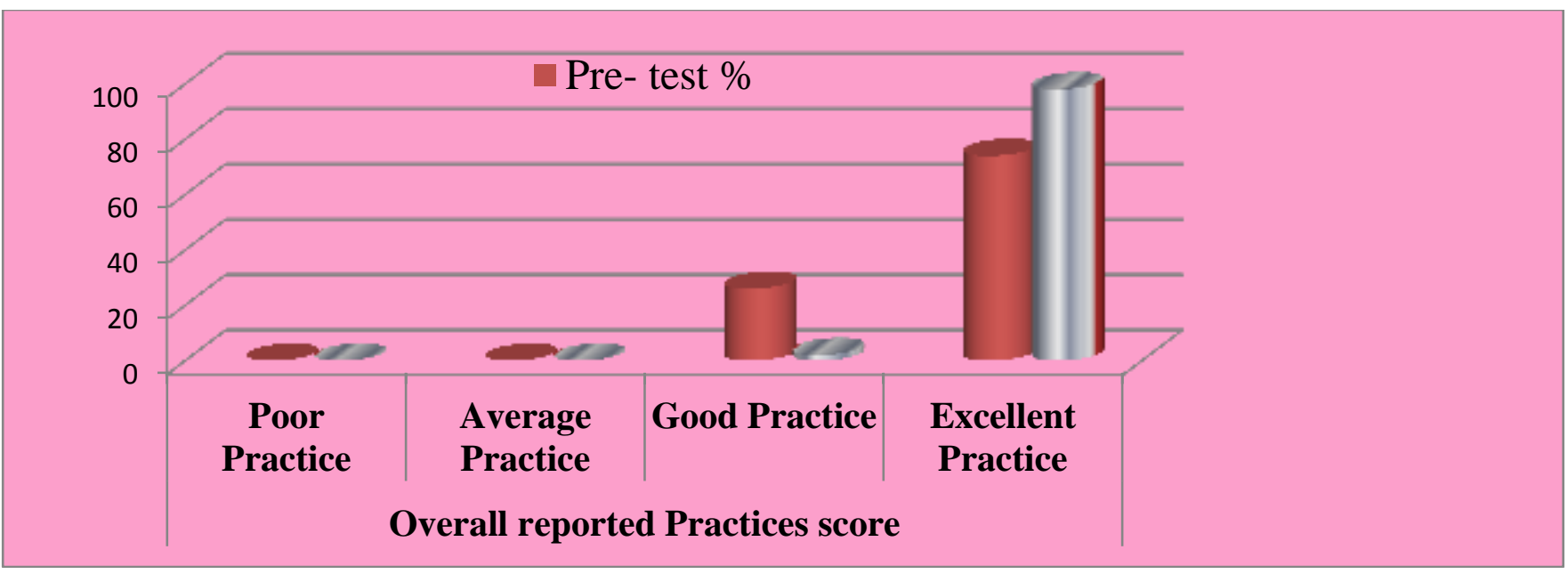

Fig NO: 4 Distribution of Subjects according to the overall reported Practices scores in pre-test \& post-test.

PART E

Table 5 -Comparison of the Subjects according to the area wise mean scores of Knowledge in pre-test and post-test.

\begin{tabular}{|c|c|c|c|c|c|c|c|}
\hline \multirow{2}{*}{\multicolumn{2}{|c|}{ Knowledge areas }} & \multicolumn{6}{|c|}{$\mathrm{N}=50$} \\
\hline & & Mean & S. D. & M.D. & SEMD & $\mathrm{t}$ value & value \\
\hline \multirow{2}{*}{$\begin{array}{l}\text { Disease-condition, mode of } \\
\text { transmission, sign symptoms, } \\
\text { treatment \&prevention of TB }\end{array}$} & $\begin{array}{l}\text { Pre } \\
\text { Test }\end{array}$ & 7.76 & 1.84 & \multirow{2}{*}{5.12} & \multirow{2}{*}{0.27} & \multirow{2}{*}{19.14} & \multirow{2}{*}{0.00} \\
\hline & $\begin{array}{l}\text { Post } \\
\text { Test }\end{array}$ & 12.88 & 0.385 & & & & \\
\hline \multirow{2}{*}{ DOTS therapy \& its adherence } & $\begin{array}{l}\text { Pre } \\
\text { Test }\end{array}$ & 6.50 & 1.97 & \multirow{2}{*}{5.98} & \multirow{2}{*}{0.28} & \multirow{2}{*}{21.31} & \multirow{2}{*}{0.00} \\
\hline & $\begin{array}{l}\text { Post } \\
\text { Test }\end{array}$ & 12.48 & 0.646 & & & & \\
\hline
\end{tabular}

Do $=49$, level of significance is 0.05 for table value of 2.01

The Table No: 5 indicated that, the area wise Knowledge scores of pre-test \& post-test calculate ' $t$ ' value $(19.14 \&$ 21.31) were greater than the table ' $t$ ' value (2.01) at 0.05 level of significance with the degree of freedom (49) thus, the null hypothesis was rejected.

These results indicated the significance of administration of Self Instructional Module in the improvement of area wise Knowledge mean scores of Subjects. 


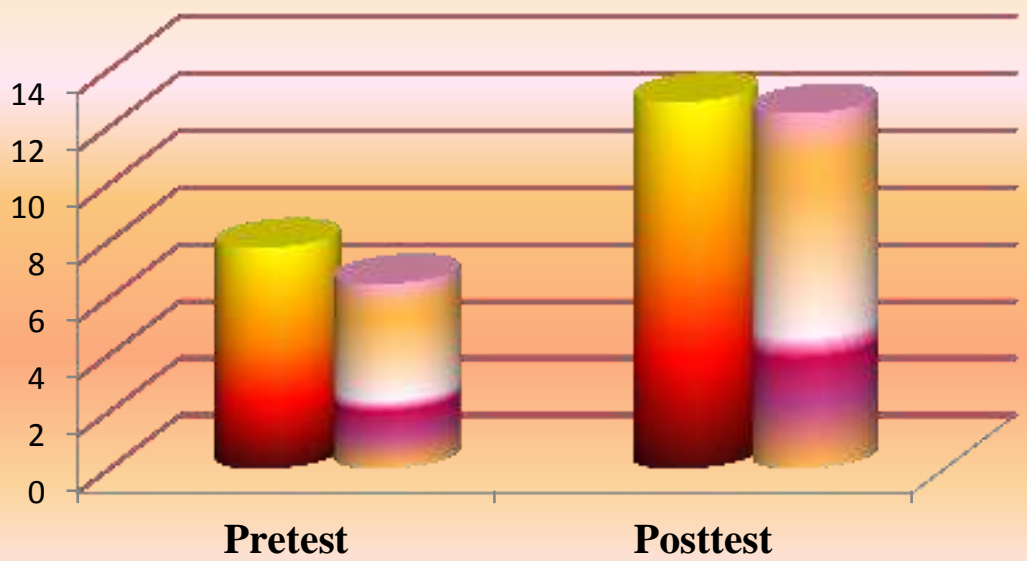

Disease-condition, mode of transmission, sign symptoms, treatment \&prevention of TB - DOTS therapy \& its adherence

Fig. 5:- Comparison of the Subjects according to area wise mean scores of Knowledge regarding disease condition, DOTS \& its adherence in the pre-test and post-test.

\section{PART-F}

Comparison of mean scores of overall Knowledge of the Subjects in pre - test and post -test.

Table 6 - Comparison of mean scores of overall Knowledge of the Subjects in pre-test and post-test.

\begin{tabular}{|l|l|l|l|l|l|l|l|}
\hline Comparison & Mean & S. D. & M.D. & SEMD & t value & $p$ \\
\cline { 1 - 8 } $\begin{array}{l}\text { Overall } \\
\text { Knowledge }\end{array}$ & Pre test & 14.26 & 3.17 & 11.1 & 0.47 & 23.67 & 0.00 \\
\cline { 2 - 4 } & Post-test & 25.36 & 0.80 & & & & \\
\hline
\end{tabular}

$\mathrm{DF}=49$, level of significance is 0.05 for table value of 2.01

The above table: 6 indicated that, calculated ' $t$ ' value (23.67) was greater than the table 't' value( 2.01) at 0.05 level of significance with the degrees of freedom being (49), thus the null hypotheses $\left(\mathrm{H}_{0}\right)$ was rejected \& $\mathrm{H}_{1}$ was accepted.

Before calculating the 't' value, Null hypothesis $\left(\mathrm{H}_{0}\right)$ was stated. These results supported the significance of Self Instructional Module in the improvement of Knowledge score of the Subjects. 


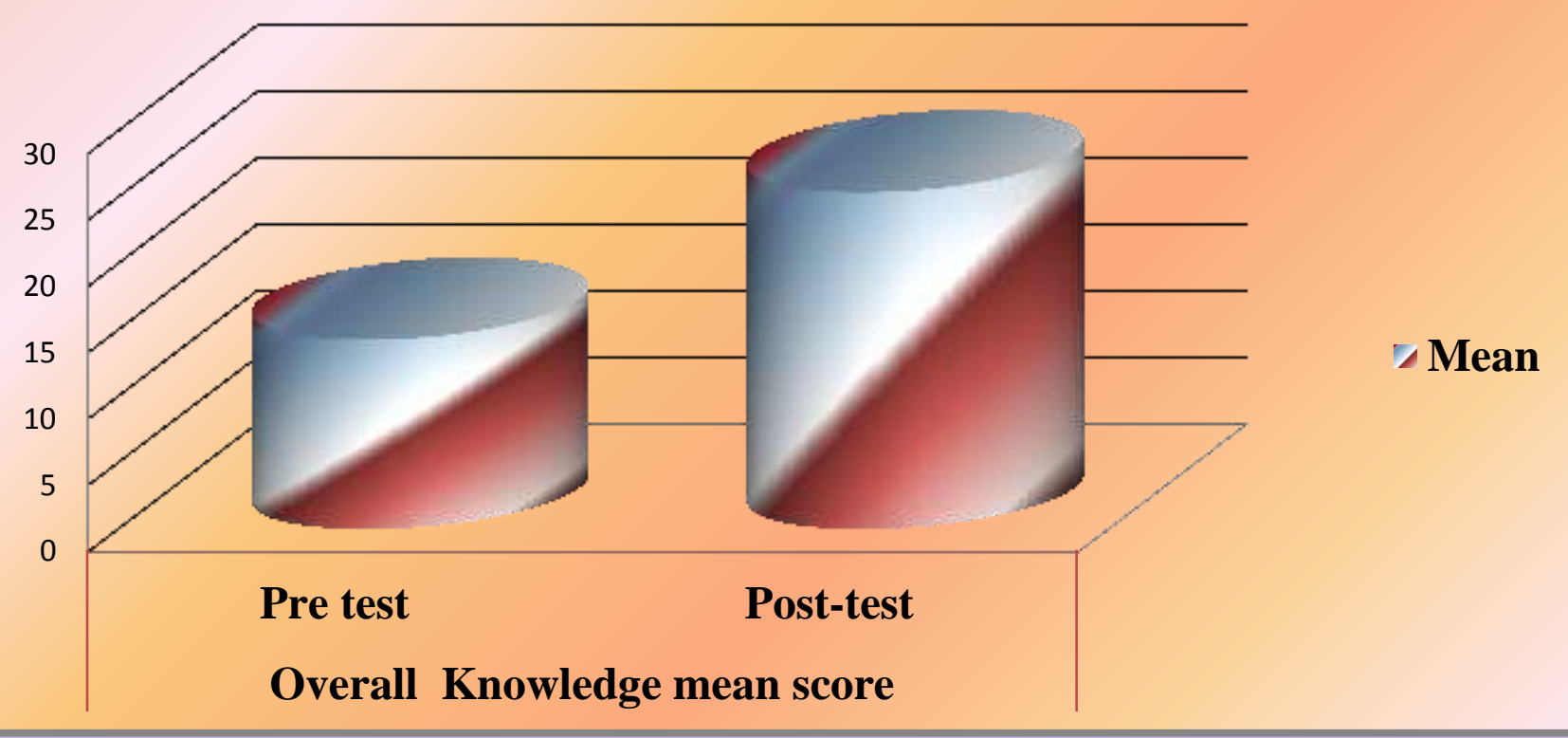

Fig. 6: Comparison of Subjects according to overall Knowledge scores in pre-test and post-test.

\section{PART-G}

Comparison of mean scores of overall self-reported Practice of the Subjects in pre-test and post-test

Table 7-Comparison of the subjects according to the mean scores of overall Practices in pre-test and post-test

\begin{tabular}{|l|l|l|l|l|l|l|l|}
\hline \multicolumn{2}{|c|}{ Comparison } & Mean & S. D. & M.D. & SEMD & $\mathrm{t}$ value & $\begin{array}{l}p \\
\text { value }\end{array}$ \\
\hline $\begin{array}{l}\text { Overall } \\
\text { Practice }\end{array}$ & Pre test & 12.04 & 1.22 & 1.08 & 0.17 & 6.31 & 0.00 \\
\cline { 2 - 9 } & Post-test & 13.12 & 0.72 & .08 & \\
\hline
\end{tabular}

$\mathrm{DF}=49$, level of significance is 0.05 for table value of 2.01

The above table: 7 highlighted that, the Calculated ' $t$ ' value (6.31) were greater than the table't' value (2.01) at 0.05 level of significance with the degrees of freedom ( 49) thus, the null hypothesis $\left(\mathrm{H}_{0}\right)$ was rejected.

Before calculating the ' $\mathrm{t}$ ' value, Null hypothesis $\left(\mathrm{H}_{0}\right)$ was stated. These results support the significance of Self Instructional Module in the improvement of Practice score of the Subjects. 


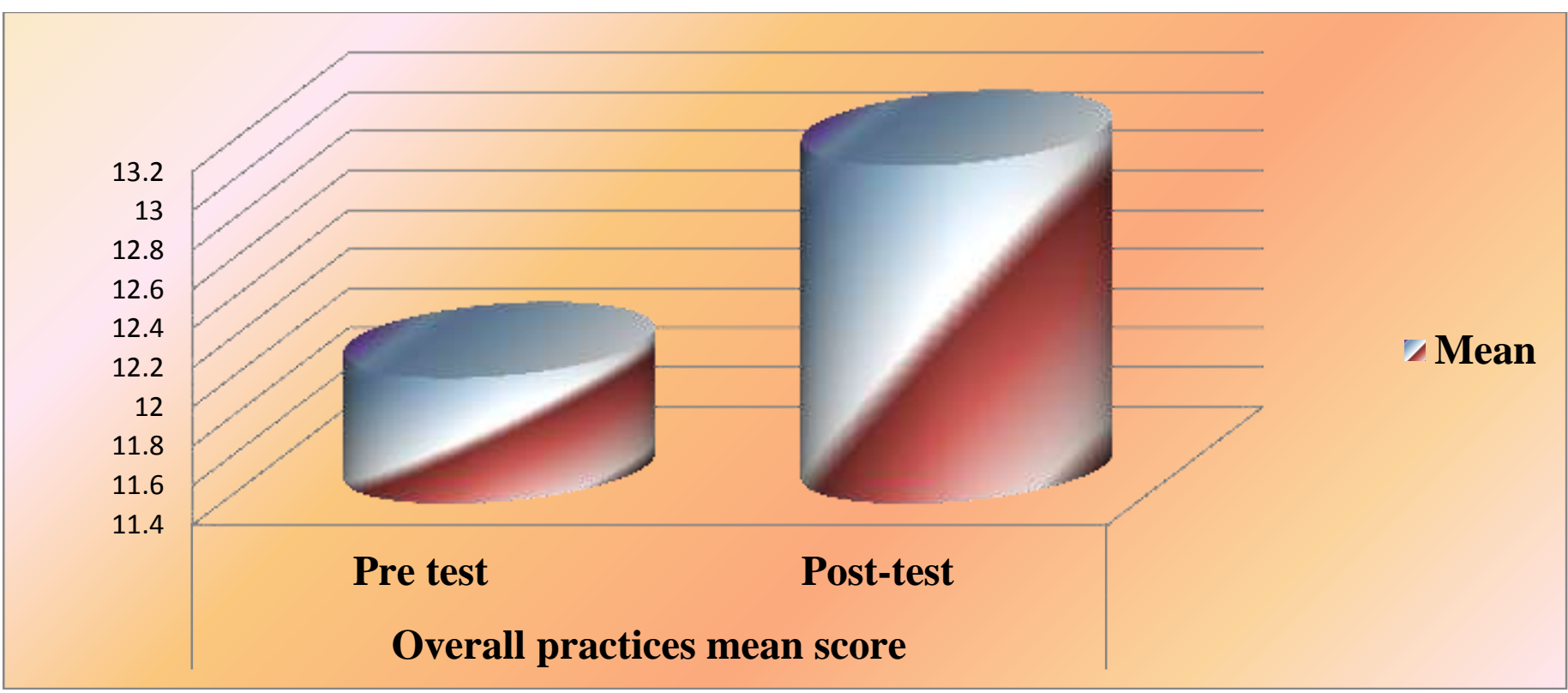

Fig. 7:- Comparison of Subjects according to of overall Practices in pre-test and post-test.

\section{References:-}

1. Park K. Parks Textbook of Preventive \& Social Medicine. Twenty Third Edition. Jabalpur (M.P.): M/S Banarasidan Bhanot Publishers; 2015.176-201.

2. Indian Pediatrics Journal Source- March13 www.tbcindia.nic.in; Vol. 50.

3. Indian nursing council Nurses Manual, Training of nurses on Tuberculosis care \& control in India, August. 2014;

4. Ghai OP, Paul VK, Bagge A et al. Essentials of Pediatrics, 6th edition. New Delhi: CBS Publishers \& Distributors Pvt.Ltd, 2005.

5. TB FACTS risk factors of TB updated 2013; cited 2013available from http:// www.cdc.gov/ TB/topic/basics/ default .html.

6. Cruz AT, Starke JR. Twice-weekly therapy for the children with Tuberculosis infection or exposure. Int J Tuberc Lung Dis. 2013 Feb;17(2):169-74. doi:10.5588/ijtld.12.0641. PubMed PMID: 23317951.

7. Liu Q, Abba K, Alejandria MM, Sinclair D, Balanag VM, Lansang MA. Reminder systems to improve patient adherence to Tuberculosis clinic appointments for diagnosis and treatment. Cochrane Database Syst Rev. 2014 Nov 18;11:CD006594.doi: 10.1002/14651858.CD006594.pub3. Review. PubMed PMID: 25403701.

8. Dr Angela J Dean, Kids in Mind Research, Mater Child and Youth Mental Health Service, Mater The children's Hospital, South Brisbane, Queensland 4101, AustraliaAccepted 13 March 2010 Published Online First 3 June 2010. 